\title{
What turns knowledge into innovative products? The role of entrepreneurship and knowledge spillovers
}

\author{
Joern H. Block • Roy Thurik • Haibo Zhou
}

Published online: 22 February 2012

(C) The Author(s) 2012. This article is published with open access at SpringerLink.com

\begin{abstract}
The knowledge spillover theory of entrepreneurship seeks to explain the fundamentals and consequences of entrepreneurship with respect to economic performance. This paper uses the knowledge spillover theory to explain different innovation outcomes. We hypothesize that a high rate of entrepreneurship facilitates the process of turning knowledge into new-to-themarket innovation but has no effect on the relationship between knowledge and new-to-the-firm innovation. Our results using European country-level and
\end{abstract}

\footnotetext{
J. H. Block · R. Thurik $(\bowtie)$

Centre for Advanced Small Business Economics, Erasmus School of Economics,

Erasmus University Rotterdam, P.O. Box 1738, 3000 DR Rotterdam, The Netherlands e-mail: thurik@ese.eur.nl

J. H. Block · R. Thurik

Erasmus Research Institute of Management (ERIM), Erasmus University Rotterdam, Rotterdam, The Netherlands
}

\section{J. H. Block}

Schöller Chair in Technology and Innovation Management, Technische Universität München, München, Germany

e-mail: block@wi.tum.de

\section{R. Thurik}

Panteia/EIM, P.O. Box 7001, 2701 AA Zoetermeer, The Netherlands

R. Thurik

GSCM-Montpellier Business School, Montpellier, France

\section{H. Zhou}

Department of Innovation Management and Strategy, University of Groningen,

P.O. Box 800, 9700 AV Groningen, The Netherlands

e-mail: h.zhou@rug.nl 
pooled OLS, fixed- and random-effects regressions show that a high rate of entrepreneurship increases the chances that knowledge will become new-to-themarket innovation. The findings highlight the importance of Schumpeterian entrepreneurship in the process of the commercialization of knowledge. We discuss the implications for entrepreneurship and innovation policy.

Keywords Innovation • Entrepreneurship - Knowledge spillovers • Patents • Commercialization of knowledge $\cdot$ Community innovation survey

JEL Classification M13 • O31

\section{Introduction}

Endogenous growth theory assumes that an economy automatically benefits from its investments in new knowledge (Lucas 1988; Romer 1990) because knowledge is a public good that can be used by an entire economy, leading to innovation and economic growth (Cantner et al. 2008). In the empirical world of the R\&D capital approach (Mansfield 1965; Griliches 1998, 2000), the development of total factor productivity (TFP) is explained using an R\&D stock variable. ${ }^{1}$ Although a great deal of evidence shows that knowledge (R\&D stock) leads to growth (TFP growth), some countries seem to benefit more from investments in new knowledge than others. The US, for example, is thought to commercialize new knowledge better than Europe, giving rise to what is referred to as the Swedish paradox (Ejermo and Kander 2006) or the European paradox (Audretsch 2007). Investment in new knowledge is only one necessary condition; new knowledge must be exploited and put to commercial use so that it can translate into stronger competitiveness and subsequent economic growth (Braunerhjelm and Svensson 2010; Carlsson et al. 2009) This barrier between knowledge and its commercialization is referred to as the knowledge filter (Acs et al. 2009; Braunerhjelm et al. 2010). ${ }^{2}$

The contribution of Acs et al. (2009) extends the microeconomic foundations of endogenous growth models (Lucas 1988; Romer 1990) through the knowledge spillover theory of entrepreneurship, which holds that knowledge creation can lead to knowledge spillovers, creating technological opportunities. Entrepreneurs then exploit these opportunities, leading to economic growth and development. New product innovations may come from both incumbent firms and start-ups. Incumbent firms mainly produce incremental innovations from the flow of knowledge, whereas start-ups tend to exploit knowledge spillovers to produce radical innovations.

\footnotetext{
${ }^{1}$ The R\&D capital approach also takes into account international effects, such as those of foreign R\&D, import shares, openness and catch-up mechanisms. See Erken et al. (2009).

${ }^{2}$ This concept was first presented in two CEPR discussion papers (Acs et al. 2004, 2005).
} 
Braunerhjelm et al. (2010) use the knowledge spillover theory of entrepreneurship to explain the European or Swedish paradox (Ejermo and Kander 2006; Audretsch 2007). They develop a theoretical model in which the transformation of knowledge into economic growth depends on how knowledge diffuses through both incumbent and entrepreneurial activity. The entrepreneur is the "missing link in converting knowledge into economically relevant knowledge" (Braunerhjelm et al. 2010, p. 105). Based on OECD data from 1981 to 2002, they show that entrepreneurship Granger-causes economic growth and that this effect increased in the 1990s, as the knowledge economy began to grow.

Our paper links the knowledge spillover theory of entrepreneurship (Acs et al. 2009) to empirical innovation research using different types of innovation as outcome variables. Whereas the empirical model of Braunerhjelm et al. (2010) tests the effects of entrepreneurship on economic growth when the link to innovation is indirect, we seek to explain the effect of entrepreneurship on the transformation of knowledge into innovation. A research gap exists in the link between the knowledge spillover theory of entrepreneurship and empirical research about innovation and the commercialization of knowledge (Carlsson et al. 2009; Braunerhjelm and Svensson 2010). In our paper, we will discriminate between innovations that are new to the market and those that are new to the firm. Based upon the knowledge spillover theory, we hypothesize that a high rate of entrepreneurship facilitates the process of turning knowledge into new-to-the-market innovation but has no important effect on the relationship between knowledge and new-to-the-firm innovation.

Our focus, and, therefore, our unit of observation, is at the country level rather than at the individual-firm level. We use a panel dataset that covers the innovation activity of 21 European countries in four waves, corresponding to the period from 1996 to 2006. The results clearly show that entrepreneurship, measured as the business ownership rate, is an important driver for turning knowledge into new-to-the-market innovation but has no impact on new-to-the-firm innovation. This finding is precisely what the knowledge spillover theory of entrepreneurship and prior entrepreneurship research predicts. Entrepreneurs as individuals are considered risk takers (Kihlstrom and Laffont 1979) who are tolerant of ambiguity (Schere 1982). Thus, they play an important role when risk and uncertainty are involved, such as new-tothe-market innovations, but less so for new-to-the-firm innovations, for which product uncertainty and risk are much lower. Our paper contributes to our understanding of the knowledge spillover theory, particularly why and under what conditions entrepreneurship leads to innovation and economic growth. This paper also enhances understanding of the types of innovation that are most closely related to entrepreneurship.

Following this introduction, Section 2 introduces the literature on economic growth, knowledge spillovers and types of innovation. Section 3 develops our hypotheses using the knowledge spillover theory of entrepreneurship and links this theory to different innovation outcomes. Section 4 summarizes our data and the empirical model. Section 5 reports our regression results, which are discussed in Section 6. Section 7 concludes. 


\section{Related literature}

\subsection{Entrepreneurship and economic growth}

A small part of the literature on the economics of entrepreneurship focuses on the role of entrepreneurship as it impacts economic growth. In this literature, entrepreneurship is often presented as an additional production factor, called entrepreneurship capital (Audretsch 2007). In this sense, however, it does not contribute to our understanding of the exact mechanism of the transformation of knowledge into economic growth. The main question is why entrepreneurship leads to growth. Literature surveys of the influence of entrepreneurship on economic growth (Van Praag and Versloot 2007; Braunerhjelm 2008; Parker 2009; Carree and Thurik 2010) are relatively vague, except to say that entrepreneurship is expected to lead to diversity, innovation, competition, employment, and learning, at which point economic growth occurs. Among the studies of entrepreneurship and economic growth, Baumol (2002) is the clearest in stating that innovation is the essence of economic growth. The knowledge spillover theory of entrepreneurship (Acs et al. 2009; Braunerhjelm et al. 2010) is an important step in understanding the microeconomic foundations of how entrepreneurship leads to economic growth. In the three succeeding subsections, we briefly summarize the literature on knowledge spillovers and the knowledge spillover theory of entrepreneurship, and then we turn to the main focus of this study: the different types of innovation and their relation to knowledge.

\subsection{Knowledge spillovers and geographical boundaries}

The production of knowledge can lead to spillovers when individuals or organizations other than the creators of knowledge benefit from the knowledge that the creator has produced. Thus, by investing in knowledge, a firm not only increases its own level of knowledge but also contributes to the aggregate stock of knowledge (Romer 1986; Lucas 1993; Griliches 1998). For example, when securing a patent, a firm produces new knowledge, and the information included in the patent becomes accessible to the general public and to competitors. A competitor may use the information from the patent for its own research and invest in related knowledge, and this related knowledge may lead to new patents or innovative products. In other words, knowledge may spill over from one firm to another. There is extensive research on knowledge spillovers in multiple contexts, such as technology transfer (e.g., Anselin et al. 1997; Carlsson and Fridh 2002), innovation networks (e.g., Breschi and Lissoni 2001), technology clusters (e.g., Werker and Athreye 2004), and the evolution of industries (e.g., Malerba 2006). This research has shown that geographical proximity matters if knowledge spillovers are to occur. Although knowledge may spill over to firms or individuals far from the creator of knowledge, the literature has shown that spillovers are more likely to occur on a local level (Jaffe et al. 1993; Anselin et al. 1997; Varga 2000; Keller 2002; Bottazzi and 
Peri 2003). Anselin et al. (1997) show that university research and regional innovative activities are positively related, and there is evidence that university research impacts business $\mathrm{R} \& \mathrm{D}$ both directly and indirectly. Using a dataset that covers most of the world's innovative activity between 1970 and 1995, Keller (2002) shows that the benefits of knowledge spillovers decline with distance. However, there is evidence of an autonomous time trend towards more global knowledge diffusion.

\subsection{The knowledge spillover theory of entrepreneurship}

Entrepreneurship is identified by its role in the recognition, discovery, and creation of opportunities (Shane and Venkataraman 2000). Little is known, however, about the source of these opportunities. The knowledge spillover theory of entrepreneurship (Acs et al. 2009; Braunerhjelm et al. 2010, for a collection of recent papers, see Acs 2010) has helped to close this gap in understanding, and knowledge spillovers are now regarded as a possible source of entrepreneurial opportunities, called endogenous entrepreneurship. ${ }^{3}$ Due to the noncompetitive nature of knowledge as an asset, it may spill over so that the producers of knowledge are not able to appropriate the entire value of their knowledge for themselves. These spillovers may then serve as a source of opportunities for other firms and for individuals who want to start their own businesses (Acs et al. 2009; Braunerhjelm et al. 2010). The knowledge spillover theory of entrepreneurship holds that entrepreneurial activity is greater when there is greater investment in knowledge. This argument is supported by Audretsch and Lehmann (2005), among others, who show that regions with greater investments in new knowledge also have higher start-up rates. Another facet of the theory holds that opportunities for entrepreneurship are superior when the ability to access knowledge spillovers from geographically proximate sources is greater, based on the assumption that knowledge spillovers increase economic performance (Lucas 1988; Romer 1990; Glaeser et al. 1992; Acs and Armington 2004) and that this relationship is moderated by geographical proximity (Jaffe et al. 1993; Anselin et al. 1997; Varga 2000; Keller 2002; Bottazzi and Peri 2003). This is especially likely when the entrepreneur is located in close proximity to universities, large high-tech firms or other researchintensive institutions that produce knowledge (Anselin et al. 1997; Carlsson and Fridh 2002).

In short, the knowledge spillover theory shows how entrepreneurship can contribute to growth by helping knowledge to spill over or to permeate the filter that impedes knowledge spillover. The knowledge spillover theory attributes importance not only to the role of persons but also to regional

\footnotetext{
${ }^{3}$ The theory starts from the assumption that, given constant individual characteristics, entrepreneurial decisions are driven by context, particularly by the knowledge intensity of the context. Hence, entrepreneurship is not only driven exogenously by individual characteristics, behaviors and traits but also by the endogenous response to opportunities created by the context (Audretsch 2007).
} 
agglomerations of knowledge activities (entrepreneurship capital) that become the breeding ground for growth.

\subsection{Knowledge and types of innovation}

The literature discusses the following types of innovation and innovation indicators: (1) R\&D efforts, (2) patent measures, and (3) product-related indicators (Hauser and Zettelmeyer 1997; Kleinknecht et al. 2002). R\&D efforts comprise R\&D as a percentage of sales or assets and measure a firm's input in the innovation process. $\mathrm{R} \& \mathrm{D}$ efforts also serve to measure a firm's absorptive capacity (Cohen and Levinthal 1989) and knowledge potential. Patent measures, which comprise patent counts and patent issuances, may be interpreted as output-based measures of technological knowledge (Park and Park 2006). Product-related innovation indicators refer to measures of new product introduction. New product introductions can be differentiated into new-to-the-firm and new-to-the-market product introductions. The former category is sometimes interpreted as imitative behavior, and the latter category is interpreted as 'true' innovation (Kleinknecht et al. 2002). Due to their high degree of novelty, new-to-the-market innovations are characterized by high levels of technological and market uncertainty (Scherer et al. 2000), whereas this may not be true of new-to-the-firm innovation. The risk of customer acceptance can be reduced with a strategy of imitation because the product is already known to the market and to its customers (Bolton 1993). In conjunction with differences in the degree of uncertainty, new-to-the-market innovation should show a stronger association with patents than new-to-thefirm innovation because novelty is a central requirement for the patentability of an invention.

Our paper aggregates firm-level innovation data to the country level and then distinguishes between a country's level of new-to-the-firm and new-tothe-market innovations as outcome variables.

\section{Entrepreneurship as a factor that turns knowledge into innovation}

The purpose of this paper is to apply the knowledge spillover theory of entrepreneurship (Acs et al. 2009; Braunerhjelm et al. 2010) to analyze the effect of entrepreneurship in turning knowledge into different innovation outcomes. As summarized in the preceding section, existing literature using the knowledge spillover theory of entrepreneurship examines the sources of entrepreneurship and their effects on economic growth. The link between entrepreneurship and innovation is indirect. For example, the literature suggests that entrepreneurship increases economic output by facilitating the commercialization of knowledge, but this link has not been analyzed in detail, and no distinction has 
been made between different types of innovation (Hauser and Zettelmeyer 1997; Kleinknecht et al. 2002). This paper attempts to take the first steps in these directions by arguing that entrepreneurship is more likely to influence the process that leads knowledge to be converted into new-to-the-market innovations as opposed to new-to-the-firm innovations.

Innovation relates to two interrelated processes, the production of knowledge $^{4}$ and the exploitation of knowledge. We focus on the exploitation phase, particularly on the mechanism that turns knowledge into innovative products. The commercialization of knowledge, especially new knowledge, includes efforts such as financing product development or market research. The outcome of this process is often uncertain and requires a risk-taking attitude among the managers of the process, making the entrepreneurial attitude important at this stage. Entrepreneurs are considered different from other individuals because, for example, they are believed to have an aboveaverage level of willingness to take risks (Block et al. 2010a; Kihlstrom and Laffont 1979; Brockhaus 1980), a tolerance for ambiguity (Timmons 1976; Schere 1982), a need for achievement (McClelland 1961), and a preference for autonomy (Benz and Frey 2008; Block and Köllinger 2009). In particular, risk-taking and a tolerance for ambiguity are crucial for managing the process of commercializing new knowledge. A high rate of entrepreneurship and exposure to an entrepreneurial climate thus facilitates the process of turning knowledge into innovative products (Beugelsdijk 2007). Thus, we propose the following hypothesis:

Entrepreneurship moderates the relationship between knowledge and new-tothe-market innovation.

We hypothesize that entrepreneurship has little or no effect on turning knowledge into new-to-the-firm innovation because this type of innovation requires less risk taking and uncertainty. New-to-the-firm innovation is 'imitative' innovation and is associated with little market and/or technology uncertainty. It requires different skills and capabilities than new-to-the-market innovation, and places more importance on a firm's learning and imitation capabilities (Cohen and Levinthal 1989; Schewe 1996) than on entrepreneurship. Hence, we propose the following hypothesis:

Entrepreneurship does not moderate the relationship between knowledge and new-to-the-firm innovation.

\footnotetext{
${ }^{4}$ The production of knowledge is emphasized by Baumol (2002), who represents the Schumpeterian 1934 view that an environment in which most of the breakthrough innovation occurs in small firms and most of the improvement on those innovations and wide-scale dissemination occurs in large firms is an efficient one. See Ortega-Argilés (2009) for a survey of the various roles of small firms in the process of technological change.
} 


\section{Data and empirical model}

\subsection{Data sources}

Our study combines data from the Community Innovation Survey (CIS), ${ }^{5}$ the COMPENDIA database,${ }^{6}$ and the OECD Economic Outlook Database. ${ }^{7}$

The CIS is commissioned by the European Commission and records the innovation activity of firms in the EU member states, in EU candidate countries, and in Iceland and Norway. The first CIS was conducted in 1993 using a pilot version (CIS1). Since then, four additional surveys have been conducted: CIS2 (1996-1998), CIS3 (1998-2000), CIS4 (2002-2004), and CIS2006 (2004-2006). The survey unit of the CIS is the enterprise, and the target population is the total population of enterprises in a particular country. Because sampling rates may differ across countries, the CIS uses a stratified sampling procedure and weighting procedures to ensure that the samples are representative of the total population of enterprises in each country. The results of the firm-level CIS are aggregated and transmitted to Eurostat on a compulsory basis. CIS data are accepted in the research community and have been widely used in innovation research (Arundel 2001; Mairesse and Mohnen 2002, 2005; Hoelzl 2009).

COMPENDIA (COMParative ENtrepreneurship Data for International Analysis) is developed and maintained by EIM Business and Policy Research (a Panteia company) in the Netherlands. The database summarizes and harmonizes information about the number of business owners and the size of the labor force from the OECD databases, the ILO Yearbook of Labour Statistics and the European Observatory for SMEs. The quotient of these two variables is called the business ownership rate (Van Stel 2005). Business ownership includes all unincorporated self-employed persons and owner-managers of incorporated businesses (OMIBs) (Van Stel 2005). Although it has been argued that business ownership is not synonymous with entrepreneurship, Carree et al. (2002) acknowledge that the level of business ownership is a fair reflection of the level of entrepreneurship in a particular country. The main advantage of this harmonized dataset is that it makes entrepreneurship activity comparable across countries and over time. The latest version of the COMPENDIA consists of 23 OECD countries for the period of 1972-2007.

The OECD Economic Outlook Database indicates historical trends and future projections for a wide range of macro indicators that describe the

\footnotetext{
${ }^{5}$ Extended information is available at http://epp.eurostat.ec.europa.eu/portal/page/portal/science technology_innovation/data/database (accessed September 7, 2009).

${ }^{6}$ Extended information is available at http://data.ondernemerschap.nl (accessed September 7, 2009).

${ }^{7}$ For detailed information on the CIS data set, we refer to http://epp.eurostat.ec.europa.eu/ portal/page/portal/microdata/cis/publications (accessed September 7, 2009) and http://stats.oecd. org/wbos/index.aspx?r=582080 (accessed September 7, 2009).
} 
demographic, social, economic and environmental developments of a country, including the gross domestic product, rate of unemployment and deflators and prices. The dataset encompasses longitudinal information on macro indicators from the 30 OECD member countries and 6 selected non-OECD countries. We rely on this database to build our country-specific control variables.

Our final assembled dataset includes aggregated information on innovation activity from manufacturing firms (NACE $15-37),{ }^{8}$ business ownership rates, and macro indicators for 21 European countries ${ }^{9}$ in four waves during the period from 1996 to 2006. We restrict our sample to the manufacturing sector to ensure that our results are not driven by differences in industry structure between countries. Because not all countries are included in each wave, our final dataset takes the form of an unbalanced panel dataset.

\subsection{Dependent variables}

The measurement of innovation includes various dimensions and varies according to firms and their life-cycle phases. Innovation and its performance can be measured in many ways: by the turnover of new products, increases in productivity or decreases in production cost as a result of introducing new processes, or customer satisfaction with new products or services (for overviews, see Hauser and Zettelmeyer 1997; Kleinknecht et al. 2002). The CIS measures innovation performance in two ways: (1) shares of turnover attributable to new or significantly improved products that are new to the firm (variable new-to-the-firm innovation) and (2) shares of turnover attributable to new or significantly improved products that are new to the market (variable new-to-the-market innovation). With respect to new-to-the-firm innovation, the CIS asks respondents to state the share of "goods and service innovations introduced during the last three years that were only new to your firm (your enterprise introduced a new or significantly improved good or service that was already available from your competitors in your market)". With respect to new-to-the-market innovation, the CIS asks the respondents to report the share of "goods and service innovations introduced during the last three years that were new to your market (your enterprise introduced a new or significantly improved good or service onto your market before your competitors) [...]".

As noted in our theory section, we argue that entrepreneurship and an entrepreneurial attitude are particularly important with regard to new-to-themarket innovation and are less important for new-to-the-firm innovation.

\footnotetext{
${ }^{8}$ For the NACE codes, see http://stats.oecd.org/glossary/detail.asp?ID=1713 (accessed September 7, 2009).

${ }^{9}$ The countries are Austria, Belgium, Czech Republic, Denmark, Finland, France, Germany, Greece, Hungary, Iceland, Ireland, Italy, Luxembourg, Netherlands, Norway, Poland, Portugal, Slovakia, Spain, Sweden, and the United Kingdom.
} 


\subsection{Independent variables}

Rate of knowledge-intensive firms As discussed above, the production of new knowledge is a crucial factor that leads to innovation. We measure a country's level of knowledge as the share of firms that applied for at least one patent in the survey year. We consider this measure a good proxy for knowledge in the context of this study because patents are property rights granted by a patent authority, such as the European Patent Office (EPO). For a patent to be granted, the invention must be non-trivial and must have potential commercial value. Patents have been used in a number of studies as a proxy for knowledge and knowledge spillover (Jaffe et al. 1993, 2000; Acs et al. 2002; Furman et al. 2002). We use data obtained from the CIS. As a robustness check, as proxies for knowledge production, we use alternative measures, such as a country's gross expenditure on R\&D or its level of business R\&D. We believe, however, that patent-based measures are more appropriate than R\&D-based measures for our particular research question because our paper examines the role of entrepreneurship in turning 'commercializable' knowledge into innovation. Patents constitute an intermediate output of knowledge production (Kleinknecht et al. 2002) and are proxies for knowledge that can be commercialized. Not surprisingly, we find that our patent-based knowledge measure correlates strongly with a country's gross expenditure on R\&D ( $r=$ $0.68, p<0.01)$ and/or its level of business $\operatorname{R} \& \mathrm{D}(r=0.69, p<0.01)$.

Entrepreneurship rate Because of the heterogeneous context of entrepreneurship, there is no unique variable that measures entrepreneurship or entrepreneurial climate. Commonly used measures are self-employment rates, business ownership rates, and numbers of new firm start-ups. We use the business ownership rate to measure entrepreneurship. Our results also hold when we use the rate of self-employment as a proxy for entrepreneurship. The business ownership rate is calculated as the share of business owners in the total labor force. Business owners are defined as individuals whose main occupation is self-employment, including owner-managers of incorporated businesses. The data are obtained from COMPENDIA. As an alternative entrepreneurship measure, we could have used data from the Global Entrepreneurship Monitor (GEM) (Acs and Varga 2005; Reynolds et al. 2005). However, there is little overlap between the CIS data, which we used to construct our two dependent variables, new-to-the-firm innovation and newto-the-market innovation, and the GEM data. In particular, we would not be able to run panel data regressions and control for unobserved heterogeneity.

Control variables To control for macro-economic influences, two macroeconomic variables are included in the regression models, GDP and GDP per capita. These variables are taken from the OECD Economic Outlook Database. To achieve comparability over time, the values of GDP and GDP per capita are adjusted to 1995 prices. Both variables are represented as logged values and refer to a country's size or level of wealth. As robustness checks, 
we also include the variables share of small firms and share of venture capital investments in GDP as additional controls.

\subsection{Empirical model}

The following two pooled OLS equations are used for the empirical analysis: $I_{i, t}=\alpha+\beta_{1}\left(K_{i, t}\right)+\beta_{2}\left(E_{i, t}\right)+\beta_{3}\left(K_{i t} E_{i t}\right)+\beta_{4}\left(\right.$ Controls $\left._{i, t}\right)+\beta_{5}\left(\right.$ Years $\left._{t}\right)+\varepsilon_{i, t}$, where $I$ is either new-to-the-market innovation (the share of turnover attributable to new or significantly improved products that are new to the market) or new-to-the-firm innovation (the share of turnover attributable to new or significantly improved products that are new to the firm); $K$ denotes the rate

Table 1 Description of variables

\begin{tabular}{|c|c|c|}
\hline Variable & Description & Data source \\
\hline $\begin{array}{l}\text { New-to-the-market } \\
\text { innovation (in \%) }\end{array}$ & $\begin{array}{l}\text { CIS question: "What is the percentage } \\
\text { of total turnover from goods and service } \\
\text { innovations introduced during the last } \\
\text { three years that were new to the } \\
\text { market?" The question was included in } \\
\text { CIS2 (1996-1998), CIS3 (1998-2000), } \\
\text { CIS4 (2002-2004), and CIS2006 } \\
\text { (2004-2006) }\end{array}$ & $\begin{array}{l}\text { Community Innovation } \\
\text { Survey: CIS2, CIS3, } \\
\text { CIS4, and CIS2006 } \\
\text { (only answers from } \\
\text { manufacturing firms) }\end{array}$ \\
\hline $\begin{array}{l}\text { New-to-the-firm } \\
\text { innovation (in \%) }\end{array}$ & $\begin{array}{l}\text { CIS question: "What is the percentage } \\
\text { of total turnover from goods and service } \\
\text { innovations introduced during the last } \\
\text { three years that were new to the firm?" } \\
\text { The question was included in CIS2 } \\
\text { (1996-1998), CIS3 (1998-2000), } \\
\text { CIS4 (2002-2004), and CIS2006 } \\
\text { (2004-2006) }\end{array}$ & $\begin{array}{l}\text { Community Innovation } \\
\text { Survey: CIS2, CIS3, } \\
\text { CIS4, and CIS2006 } \\
\text { (only answers from } \\
\text { manufacturing firms) }\end{array}$ \\
\hline Ln (GDP) & $\begin{array}{l}\text { Natural logarithm of Gross Domestic } \\
\text { Product in million US \$; in purchasing } \\
\text { power parities adjusted to prices from } \\
1995\end{array}$ & $\begin{array}{l}\text { OECD Economic Outlook } \\
\text { Database } 2009\end{array}$ \\
\hline Ln (GDP per capita) & $\begin{array}{l}\text { Natural logarithm of Gross Domestic } \\
\text { Product divided by total population; } \\
\text { US dollars; in purchasing power } \\
\text { parities adjusted to prices from } 1995\end{array}$ & $\begin{array}{l}\text { OECD Economic Outlook } \\
\text { Database } 2009\end{array}$ \\
\hline $\begin{array}{l}\text { Entrepreneurship } \\
\text { rate (in \%) }\end{array}$ & $\begin{array}{l}\text { The number of business owners } \\
\text { (excluding the agricultural sector) } \\
\text { as a percent of the total labor force }\end{array}$ & $\begin{array}{l}\text { COMPENDIA } \\
\text { (version of 2007) }\end{array}$ \\
\hline $\begin{array}{l}\text { Rate of knowledge- } \\
\text { intensive firms } \\
\text { (in \%) }\end{array}$ & $\begin{array}{l}\text { CIS question: "During the last three } \\
\text { years, did your enterprise apply for } \\
\text { a patent?" The question was included } \\
\text { in CIS2 (1996-1998), CIS3 (1998-2000), } \\
\text { CIS4 (2002-2004), and CIS2006 } \\
\text { (2004-2006). The variable is calculated } \\
\text { as the number of firms that answered } \\
\text { 'yes' as a percentage of the total } \\
\text { number of firms }\end{array}$ & $\begin{array}{l}\text { Community Innovation } \\
\text { Survey: CIS2, CIS3, } \\
\text { CIS4, and CIS2006 } \\
\text { (only answers from } \\
\text { manufacturing firms) }\end{array}$ \\
\hline
\end{tabular}


of knowledge-intensive firms measured by the share of firms that applied for at least one patent in the last three years; $E$ denotes the business ownership rate as a proxy for the entrepreneurship rate; Controls denotes the control variables, which are the natural logarithm of GDP and the natural logarithm of GDP per capita; Years corresponds to year dummies for the years 1998, 2000, 2004, and 2006; and $i$ and $t$ are country and year indices, respectively. Table 1 describes the construction of the variables in more detail. To conduct a robustness check, we estimated random- and fixed-effects regressions (Wooldridge 2002) using the same variables.

\section{Results}

\subsection{Descriptive statistics}

Descriptive statistics for the variables are presented in Table 2. The mean percentage of turnover for new-to-the-market innovations is $8 \%$, with a variation of $1 \%$ to $24 \%$. The mean percentage of turnover for new-to-the-firm innovations is $13 \%$, with a variation of $4 \%$ to $41 \%$. The mean rate of entrepreneurship is $11 \%$, with a variation of $5 \%$ to $21 \%$, and the mean proportion of firms that applied for a patent is $10 \%$, with a range of $2 \%$ to $27 \%$. Table 3 shows a correlation table. The variables new-to-the-market innovation and new-tothe-firm innovation are not correlated $(r=0.05, p>0.1)$, indicating that they relate to different characteristics of new products (and countries). Except for the correlations between knowledge and the natural logarithm of GDP per capita as well as knowledge and new-to-the-firm innovation, all correlations are below 0.5 . With innovation and imitation performance as the dependent variables, the variance inflation factors (VIFs) do not exceed 3. Although we conclude that multicollinearity is not likely to be an issue, we use stepwise regressions to learn about the interrelationships among the independent variables.

Table 2 Descriptive statistics

\begin{tabular}{llllll}
\hline Variables & Mean & Median & Std. dev. & Min. & Max. \\
\hline New-to-the-market innovation (in \%) & 8.12 & 7.30 & 3.96 & 1.00 & 23.90 \\
New-to-the-firm innovation (in \%) & 12.84 & 10.40 & 7.71 & 3.70 & 41.10 \\
Ln(GDP) & 12.47 & 12.25 & 1.17 & 8.97 & 14.55 \\
GDP (in million US \$) & 486,722 & 208,854 & 565,727 & 7,867 & $2,076,601$ \\
Ln(GDP per capita) & 10.03 & 10.08 & 0.31 & 9.30 & 10.96 \\
GDP per capita (in US \$) & 23,734 & 23,820 & 7,985 & 10,985 & 57,282 \\
Entrepreneurship rate (in \%) & 10.78 & 9.80 & 3.90 & 5.20 & 21.00 \\
Rate of knowledge-intensive firms (in \%) & 10.14 & 9.70 & 6.38 & 1.60 & 27.20 \\
\hline
\end{tabular}

$N=57$ observations from 21 countries

Data sources: CIS, COMPENDIA, and OECD Economic Outlook Database 
Table 3 Correlations and variance inflation factors

\begin{tabular}{|c|c|c|c|c|c|c|c|}
\hline & Variables & 1 & 2 & 3 & 4 & 5 & VIFs \\
\hline 1 & New-to-the-market innovation & & & & & & \\
\hline 2 & New-to-the-firm innovation & 0.05 & & & & & \\
\hline 3 & Enterepreneurship rate & 0.01 & -0.20 & & & & 1.69 \\
\hline 4 & Rate of knowledge-intensive firms & 0.02 & $0.51 *$ & $-0.48^{*}$ & & & 2.97 \\
\hline 5 & $\ln ($ GDP per captia) & $-0.26^{*}$ & 0.09 & $-0.34^{*}$ & $0.56^{*}$ & & 1.83 \\
\hline 6 & $\ln (\mathrm{GDP})$ & 0.10 & $0.32^{*}$ & $0.24^{*}$ & $0.27^{*}$ & -0.15 & 1.59 \\
\hline
\end{tabular}

${ }^{*} p<0.10$, two-tailed tests

$N=57$ observation from 21 countries; VIF = variance inflation factor

Year dummies are included in the calculation of the VIFs

The VIF values are all below 3 in the regressions

Data sources: CIS, COMPENDIA, and OECD Economic Outlook Database

\subsection{Pooled OLS regressions of new-to-the-market innovation}

Table 4 shows the results of pooled OLS regressions with respect to new-tothe-market innovation (standard errors are clustered). The empirical analysis is conducted in four steps with four representative models. Model I is the

Table 4 Pooled OLS regressions on new-to-the-market innovation

\begin{tabular}{|c|c|c|c|c|}
\hline Independent variables & $\begin{array}{l}\text { Model I } \\
\text { Coeff. (SE) }\end{array}$ & $\begin{array}{l}\text { Model II } \\
\text { Coeff. (SE) }\end{array}$ & $\begin{array}{l}\text { Model III } \\
\text { Coeff. (SE) }\end{array}$ & $\begin{array}{l}\text { Model IV } \\
\text { Coeff. (SE) }\end{array}$ \\
\hline \multicolumn{5}{|l|}{ Macro-economic variables } \\
\hline $\ln (\mathrm{GDP})$ & $0.28(0.49)$ & $-0.21(0.67)$ & $-0.34(0.61)$ & $-0.70(0.66)$ \\
\hline $\ln$ (GDP per capita) & $-3.17(1.57)^{\dagger}$ & $-6.54(2.29)^{* *}$ & $-6.69(2.19)^{* *}$ & $-7.38(2.25)^{* *}$ \\
\hline $\begin{array}{l}\text { Rate of knowledge-intensive } \\
\text { firms }\end{array}$ & & $0.27(0.14)^{\dagger}$ & $0.31(0.12)^{*}$ & $-0.33(0.24)$ \\
\hline Entrepreneurship rate & & & $0.09(0.20)$ & $-0.38(0.19)^{\dagger}$ \\
\hline $\begin{array}{l}\text { Rate of knowledge-intensive } \\
\text { firms X entrepreneurship rate }\end{array}$ & & & & $0.07(0.03)^{* *}$ \\
\hline \multicolumn{5}{|c|}{ Year dummies (reference year: 1998) } \\
\hline Year 2000 & $1.94(1.45)$ & $2.94(1.76)$ & $3.01(1.78)$ & $3.25(1.70)^{\dagger}$ \\
\hline Year 2004 & $1.70(1.08)$ & $2.81(1.50)^{\dagger}$ & $2.91(1.39)^{*}$ & $3.13(1.29)^{*}$ \\
\hline Year 2006 & $2.64(0.79)^{* *}$ & $3.98(1.33)^{* *}$ & $4.16(1.12)^{* *}$ & $3.13(1.29)^{*}$ \\
\hline Constant & $34.83(17.98)^{\dagger}$ & $71.11(27.33)^{*}$ & $72.77(26.97)^{*}$ & $88.43(26.70)^{* *}$ \\
\hline F-value & $5.31^{* *}$ & $4.67^{* *}$ & $4.60^{* *}$ & $6.53^{* *}$ \\
\hline $\begin{array}{l}\mathrm{p} \text {-value Breusch-Pagan test } \\
\text { for random effects }\end{array}$ & 0.01 & 0.05 & 0.10 & 0.14 \\
\hline$R^{2}$ & 0.13 & 0.22 & 0.22 & 0.29 \\
\hline$R^{2}$ (without year dummies) & 0.07 & 0.11 & 0.11 & 0.17 \\
\hline Adjusted $R^{2}$ & 0.04 & 0.12 & 0.11 & 0.18 \\
\hline $\mathrm{N}$ observations (countries) & $57(21)$ & $57(21)$ & $57(21)$ & $57(21)$ \\
\hline
\end{tabular}

$\mathrm{SE}=$ robust and clustered standard errors; Coeff. = regression coefficient

Data sources: CIS, COMPENDIA, and OECD Economic Outlook Database

${ }^{\dagger}$ : at 0.1 significance level; ${ }^{*}$ : at 0.05 significance level; ${ }^{* *}$ : at 0.01 significance level; two-tailed tests We also calculated the effect of a time trend variable with year $1998=1$, year $2000=2$, year $2004=3$, and year 2006=4. The coefficients (SE) are as follows: Model I: $\beta=0.759(0.31)^{*}$; Model II: $\beta=1.13(0.42)^{*}$; Model III: $\beta=1.18(0.33)^{* *}$; Model IV: $\beta=1.22(0.32)^{* *}$ 
baseline model, which includes the macro-economic control variables and the year dummies. This model explains $13 \%$ of the variation in new-to-the-market innovation (our dependent variable). In Model II, the knowledge variable is added to the baseline model to test the effect of knowledge on new-tothe-market innovation. As expected, a higher share of knowledge-intensive firms leads to a higher share of new-to-the-market innovations $(\beta=0.27, p<$ $0.1)$. The positive relationship of knowledge and new-to-the-market innovation increases the explanatory power of the model by $9 \%$ and confirms that the stock of knowledge is an important determinant of innovation performance. Model III includes the entrepreneurship variable in the model and shows that the rate of entrepreneurship itself does not seem to affect new-to-themarket innovation $(\beta=0.09, p=0.67)$. The effect of the knowledge variable hardly increases, from $\beta=0.27(p<0.10)$ in Model II to $\beta=0.31(p<0.05)$ in Model III. Model IV tests the moderation effect of entrepreneurship, and the interaction term shows a positive effect $(\beta=0.07, p<0.05)$. The explanatory power increases by $7 \%$, from $R^{2}=22 \%$ in Model III to $R^{2}=$ $29 \%$ in Model IV. A higher rate of entrepreneurship seems to increase the rate by which knowledge leads to new-to-the-market innovations, indicating that a higher rate of entrepreneurship facilitates the commercialization of knowledge. Entrepreneurship is found to moderate the relationship between knowledge and new-to-the-market innovation. To determine whether the OLS model produces consistent results, we perform a Breusch-Pagan test for random effects (Breusch and Pagan 1980). The test shows significant results for Models I-II and insignificant results for Models III-IV. Thus, we conclude that the OLS coefficients are consistent in Models III-IV and inconsistent in Models I-II.

\subsection{Pooled OLS regressions of new-to-the-firm innovation}

As a further test of the role of entrepreneurship, we investigate whether entrepreneurship does not moderate the relationship between knowledge and new-to-the-firm innovation. Table 5 presents the results of the regressions with respect to new-to-the-firm innovation and shows that knowledge clearly leads to a higher share of new-to-the-firm innovations. A higher rate of knowledgeintensive firms increases turnover with new-to-the-firm products $(\beta=0.51$, $p<0.05$, Model II). However, Table 5 also shows that entrepreneurship does not have an effect with regard to new-to-the-firm products. Neither the entrepreneurship variable included directly $(\beta=-0.29, p=0.13$, Model III) nor the interaction term ( $\beta=-0.02, p=0.65$, Model IV) shows significant results. Thus, a higher rate of entrepreneurship does not lead to more newto-the-firm products. This result confirms our proposition that entrepreneurship moderates the relationship between knowledge and new-to-the-market innovation but does not impact the relationship between knowledge and new-to-the-firm innovation. The results should be interpreted with caution because the Breusch-Pagan test for random effects (Breusch and Pagan 1980) yields significant results. OLS coefficients may be inconsistent; therefore, we 
Table 5 Pooled OLS regressions on new-to-the-firm innovation

\begin{tabular}{lllll}
\hline Independent variables & $\begin{array}{l}\text { Model I } \\
\text { Coeff. (SE) }\end{array}$ & $\begin{array}{l}\text { Model II } \\
\text { Coeff. (SE) }\end{array}$ & $\begin{array}{l}\text { Model III } \\
\text { Coeff. (SE) }\end{array}$ & $\begin{array}{l}\text { Model IV } \\
\text { Coeff. (SE) }\end{array}$ \\
\hline $\begin{array}{l}\text { Macro-economic variables } \\
\quad \text { ln(GDP) }\end{array}$ & $1.91(1.29)$ & $0.98(0.94)$ & $1.40(1.20)$ & $1.52(1.42)$ \\
$\quad \ln ($ GDP per capita) & $2.50(2.12)$ & $-3.89(2.34)$ & $-3.41(2.04)$ & $-3.19(2.10)$ \\
Rate of knowledge-intensive & & $0.51(0.18)^{*}$ & $0.39(0.13)^{* *}$ & $0.59(0.48)$ \\
$\quad$ firms & & & $-0.29(0.19)$ & $-0.14(0.23)$ \\
Entrepreneurship rate & & & $-0.02(0.05)$ \\
Rate of knowledge-intensive & & & & \\
$\quad$ firms X entrepreneurship rate & & & & \\
Year dummies (reference year: 1998$)$ & $-0.95(1.92)$ & $0.96(2.02)$ & $0.73(1.86)$ & $0.65(1.90)$ \\
$\quad$ Year 2000 & $-9.53(2.04)^{* *}$ & $-7.44(1.71)^{* *}$ & $-7.78(1.71)^{* *}$ & $-7.85(1.75)^{* *}$ \\
$\quad$ Year 2004 & $-10.43(2.28)^{* *}$ & $-7.88(2.14)^{* *}$ & $-8.48(1.91)^{* *}$ & $-8.53(1.95)^{* *}$ \\
$\quad$ Year 2006 & $-30.58(32.95)$ & $38.23(24.64)$ & $32.81(23.74)$ & $27.82(29.92)$ \\
Constant & $6.51^{* *}$ & $6.93^{* *}$ & $6.13^{* *}$ & $6.84^{* *}$ \\
$\quad F$-value & 0.01 & 0.11 & 0.05 & 0.04 \\
$p$-value Breusch-Pagan test & & & & \\
$\quad$ for random effects & 0.50 & 0.59 & 0.60 & 0.61 \\
$R^{2}$ & 0.15 & 0.33 & 0.33 & 0.33 \\
$R^{2}$ (without year dummies) & 0.45 & 0.54 & 0.55 & 0.54 \\
Adjusted $R^{2}$ & $57(21)$ & $57(21)$ & $57(21)$ & $57(21)$ \\
$\quad$ N observations (countries) & & &
\end{tabular}

$\mathrm{SE}=$ robust and clustered standard errors; Coeff. $=$ regression coefficient

Data sources: CIS, COMPENDIA, and OECD Economic Outlook Database

${ }^{\dagger}$ : at 0.1 significance level; *: at 0.05 significance level; ${ }^{* *}$ : at 0.01 significance level; two-tailed tests We also calculated the effect of a time trend variable with year $1998=1$, year $2000=2$, year $2004=3$, and year 2006 $=4$. The coefficients (SE) are as follows: Model I: $\beta=-4.07(0.77)^{* *}$; Model II: $\beta=$ $-3.37(0.66)^{* *}$; Model III: $\beta=-3.57(0.66)^{* *}$; Model IV: $\beta=-3.71(0.71)^{* *}$

also estimate random- and fixed-effects regressions (see below for robustness checks).

\subsection{Further results from the regressions}

Our analysis yields several other interesting findings. First, there seems to be a positive time trend for new-to-the-market innovations $(\beta=1.18, p<0.01$, Table 4, Model III) and a negative time trend for new-to-the-firm innovations $(\beta=-3.57, p<0.01$, Table 5, Model III). The ratio of 'true' innovation versus imitative innovation has increased over time in the 21 European countries. This phenomenon is one of the many indicators of the switch from a 'managed' to an 'entrepreneurial' economy (Audretsch and Thurik 2000, 2001). Second, the regressions for new-to-the-firm innovation have higher $R^{2}$ values than the regressions for new-to-the-market innovation $\left(R^{2}=61 \%\right.$ vs. $29 \%$ in Model IV) because of the effect of the year dummies. The inclusion of year dummies explains $42 \%$ of the variation in new-to-the-firm innovation but explains only $5 \%$ of the variation in new-to-the-market innovation. The autonomous decline in new-to-the-firm innovation seems to override the autonomous increase in new-to-the-market innovation. This phenomenon is one of many indicators of 
a decline in the competitiveness of European countries. Finally, the finding that knowledge plays a role in both new-to-the-market innovation $(\beta=0.27$, $p<0.1$, Table 4, Model II) and new-to-the-firm innovation $(\beta=0.51, p<$ 0.05 , Table 5, Model II) supports our expectations and shows that investments in knowledge increase a country's level of absorptive capacity (Cohen and Levinthal 1989), which has an effect on both types of innovation.

\subsection{Robustness checks}

To check the robustness of our results, we estimate random- and fixed-effects models (see Tables 6 and 7). Both models confirm our main finding that entrepreneurship moderates the relationship between knowledge and newto-the-market innovation (Table 6: Model II: $\beta=0.07, p=0.03$; Model IV: $\beta=0.12, p=0.01$ ), but the models indicate no relationship between knowledge and new-to-the-firm innovation (Table 7: Model II: $\beta=-0.04$, $p=0.46$ ). A Hausman specification test is used to compare the coefficients of the random-and fixed-effects regressions (Hausman 1978). In all estimations, the test shows an insignificant result $(p>0.10)$ because the coefficients of the random-effects model do not differ systematically from the coefficients of

Table 6 Random and fixed-effects regressions on new-to-the-market innovation

\begin{tabular}{|c|c|c|c|c|}
\hline \multirow[t]{2}{*}{ Independent variables } & \multicolumn{2}{|c|}{ Random-effects regressions } & \multicolumn{2}{|c|}{ Fixed-effects regressions } \\
\hline & $\begin{array}{l}\text { Model I } \\
\text { Coeff. (SE) }\end{array}$ & $\begin{array}{l}\text { Model II } \\
\text { Coeff. (SE) }\end{array}$ & $\begin{array}{l}\text { Model III } \\
\text { Coeff. (SE) }\end{array}$ & $\begin{array}{l}\text { Model IV } \\
\text { Coeff. (SE) }\end{array}$ \\
\hline \multicolumn{5}{|l|}{ Macro-economic variables } \\
\hline $\ln (\mathrm{GDP})$ & $-0.02(0.60)$ & $-0.40(0.67)$ & $-23.30(36.00)$ & $-9.26(37.28)$ \\
\hline $\ln$ (GDP per capita) & $-5.78(2.26)^{* *}$ & $-6.32(2.16)^{* *}$ & $31.30(49.04)$ & $21.22(50.93)$ \\
\hline $\begin{array}{l}\text { Rate of knowledge-intensive } \\
\text { firms }\end{array}$ & $0.22(0.10)^{*}$ & $-0.42(0.30)$ & $0.06(0.10)$ & $-0.91(0.34)^{*}$ \\
\hline Entrepreneurship rate & $-0.001(0.21)$ & $-0.46(0.27)^{\dagger}$ & $-0.19(0.36)$ & $-0.99(0.63)$ \\
\hline $\begin{array}{l}\text { Rate of knowledge-intensive } \\
\text { firms X entrepreneurship rate }\end{array}$ & & $0.07(0.03)^{*}$ & & $0.12(0.04)^{*}$ \\
\hline \multicolumn{5}{|c|}{ Year dummies (reference year: 1998) } \\
\hline Year 2000 & $3.09(1.65)^{\dagger}$ & $3.16(1.57)^{*}$ & $2.73(1.77)$ & $2.04(1.65)$ \\
\hline Year 2004 & $2.69(1.11)^{*}$ & 2.82 & $1.84(2.01)$ & $0.69(1.61)$ \\
\hline Year 2006 & $4.06(1.00)^{* *}$ & $4.18(0.94)^{* *}$ & $2.92(2.09)$ & 1.39 (1.79) \\
\hline Constant & $61.64(26.65)^{*}$ & $75.97(26.13)^{* *}$ & $-15.57(89.36)$ & $-81.48(80.17)$ \\
\hline Wald chi ${ }^{2}$ & $26.83^{* *}$ & $34.89^{* *}$ & & \\
\hline Hausman specification test $\mathrm{t}^{\mathrm{a}}$ & $p>0.10$ & $p>0.10$ & $p>0.10$ & $p>0.10$ \\
\hline F-value & & & $2.04^{\dagger}$ & $3.63^{* *}$ \\
\hline Rho & 0.22 & 0.20 & 0.99 & 0.97 \\
\hline$R^{2}$ within; between; overall & $0.15 ; 0.30 ; 0.21$ & $0.20 ; 0.36 ; 0.29$ & $0.21 ; 0.11 ; 0.03$ & $0.28 ; 0.12 ; 0.03$ \\
\hline $\mathrm{N}$ observations (countries) & $57(21)$ & $57(21)$ & $57(21)$ & $57(21)$ \\
\hline $\begin{array}{l}\text { Obs. per group } \\
\text { (min., avg., max.) }\end{array}$ & $1 ; 2.7 ; 4$ & $1 ; 2.7 ; 4$ & $1 ; 2.7 ; 4$ & $1,2.7,4$ \\
\hline
\end{tabular}

$\mathrm{SE}=$ robust standard errors; Coeff. $=$ regression coefficient

Data sources: CIS, COMPENDIA, and OECD Economic Outlook Database

${ }^{\dagger}$ : at 0.1 significance level; *: at 0.05 significance level; ${ }^{* *}$ : at 0.01 significance level; two-tailed tests

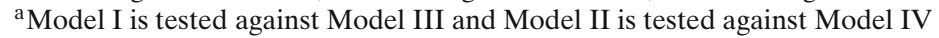


Table 7 Random and fixed-effects regressions on new-to-the-firm innovation

\begin{tabular}{|c|c|c|c|c|}
\hline \multirow[t]{3}{*}{ Independent variables } & \multicolumn{2}{|c|}{ Random-effects regressions } & \multicolumn{2}{|c|}{ Fixed-effects regressions } \\
\hline & Model I & Model II & Model III & Model IV \\
\hline & Coeff. (SE) & Coeff. (SE) & Coeff. (SE) & Coeff. (SE) \\
\hline \multicolumn{5}{|l|}{ Macro-economic variables } \\
\hline $\ln (\mathrm{GDP})$ & $1.60(0.99)$ & $1.87(1.14)$ & $-27.12(75.15)$ & $-48.92(69.13)$ \\
\hline $\ln ($ GDP per capita $)$ & $-3.07(2.64)$ & $-2.67(2.79)$ & $32.17(91.98)$ & $47.84(84.95)$ \\
\hline $\begin{array}{l}\text { Rate of knowledge-intensive } \\
\text { firms }\end{array}$ & $0.34(0.19)^{\dagger}$ & $0.68(0.52)$ & $0.12(0.19)$ & $1.63(0.76)^{*}$ \\
\hline Entrepreneurship rate & $-0.36(0.23)$ & $-0.13(0.42)$ & $-2.05(0.92)^{*}$ & $-0.81(1.13)$ \\
\hline $\begin{array}{l}\text { Rate of knowledge-intensive } \\
\text { firms X entrepreneurship rate }\end{array}$ & & $-0.04(0.06)$ & & $-0.18(0.09)^{\dagger}$ \\
\hline \multicolumn{5}{|c|}{ Year dummies (reference year: 1998) } \\
\hline Year 2000 & $0.63(2.44)$ & $0.54(2.42)$ & $-0.27(2.70)$ & $0.80(2.26)$ \\
\hline Year 2004 & $-8.07(1.88)^{* *}$ & $-8.25(1.89)^{* *}$ & $-8.84(3.69)^{*}$ & $-7.06(2.81)^{*}$ \\
\hline Year 2006 & $-8.65(2.21)^{* *}$ & $-8.79(2.19)^{* *}$ & $-8.88(4.44)^{\dagger}$ & $-6.51(3.25)^{\dagger}$ \\
\hline Constant & $28.39(30.79)$ & $19.26(35.75)$ & $54.19(240.37)$ & $156.61(196.99)$ \\
\hline Wald chi ${ }^{2}$ & $55.76^{* *}$ & $56.74^{* *}$ & & \\
\hline Hausman specification test $\mathrm{t}^{\mathrm{a}}$ & $p>0.10$ & $p>0.10$ & $p>0.10$ & $p>0.10$ \\
\hline$F$-value & & & $8.03^{* *}$ & $10.78^{* *}$ \\
\hline Rho & 0.14 & 0.20 & 0.98 & 1.00 \\
\hline$R^{2}$ within; between; overall & $0.57 ; 0.68 ; 0.60$ & $0.59 ; 0.67 ; 0.60$ & $0.62 ; 0.11 ; 0.01$ & $0.65 ; 0.17 ; 0.04$ \\
\hline N observations (countries) & $57(21)$ & $57(21)$ & $57(21)$ & $57(21)$ \\
\hline $\begin{array}{l}\text { Obs. per group } \\
\text { (min., avg., max.) }\end{array}$ & $1 ; 2.7 ; 4$ & $1 ; 2.7 ; 4$ & $1 ; 2.7 ; 4$ & $1,2.7,4$ \\
\hline
\end{tabular}

$\mathrm{SE}=$ robust standard errors; Coeff. $=$ regression coefficient

Data sources: CIS, COMPENDIA, and OECD Economic Outlook Database

${ }^{\dagger}$ : at 0.1 significance level; ${ }^{*}$ : at 0.05 significance level; ${ }^{* *}$ : at 0.01 significance level; two-tailed tests

${ }^{a}$ Model I is tested against Model III and Model II is tested against Model IV

the fixed-effects model. Nevertheless, the fact that our results also hold for a fixed-effects specification is important. We conclude that our main findings hold irrespective of country-specific variables such as openness to trade or geographic location.

As a further robustness check, we include the share of small firms (calculated from CIS data) as a control in our regression models. Because entrepreneurship is often related to small firms, our findings could also suggest that small firms face relatively lower costs of experimentation than do large firms. Potential losses from innovation at small firms have a lower limit than at larger firms (Jovanovic 1982). In addition, small firms may have an advantage because it is easier for them to reward their employees for high-value innovation (Wiggins 1995). As another robustness check, we include the share of venture capital investment in GDP (calculated from the annual yearbook of the European Venture Capital Association, EVCA) in our regressions because research by Kortum and Lerner (2000) shows that venture capital firms have a strong influence on innovation. After including these additional controls, our primary results remain unchanged, and the explanatory power of the respective regressions increases slightly. As a further robustness check, we experiment with alternative knowledge variables. To this end, we first 
regress the two alternative OECD knowledge measures (gross domestic expenditure on $R \& D$ and business expenditure on $R \& D$ ) on our knowledge variable. We include the residuals of these regressions into the new-to-themarket and new-to-the-firm innovation regressions. This not only avoids the dangers of multicollinearity but also includes the additional effect of the two alternative OECD measures. The interaction term between entrepreneurship and knowledge remains significant and has a similar magnitude (new-to-themarket innovation regression) when compared to the analyses without the newly introduced variables (i.e., the residuals of a regression of the alternative OECD measures on our knowledge variable). The newly included residual variables have non-significant effects.

Finally, we estimate seemingly unrelated regression models (SUR) and twostage simultaneous equation models in which the entrepreneurship variable is treated as endogenous. The moderation effect of entrepreneurship on the relationship between knowledge and innovation performance is similar to the effects in the other models. The estimation results relating to the robustness checks are available from the authors upon request.

\section{Discussion}

\subsection{Innovation in the knowledge spillover theory of entrepreneurship}

Both the endogenous growth theory and the R\&D capital approach point to knowledge as a major driver of economic growth. Less is known about the exact mechanism how knowledge affects growth. Thus, it is difficult for policymakers to identify policy instruments to promote growth. Glaeser et al. (1992) have established that knowledge and ideas do not spill over automatically; in the context of cities, at least, competition and diversity are required to generate growth (Audretsch 1995; Audretsch and Feldman 1996; Acs and Armington 2004). The finding that knowledge does not automatically spill over has given rise to the concept of the knowledge filter, the group of impediments that prevent knowledge from spilling over from the site where it is created to the site where it can be commercialized. Independently of the investigation of the role of knowledge, a different strand of literature emphasizes the role of entrepreneurship in economic growth. The development of this literature culminates in the view that the older 'managed' economy has been replaced by a newer 'entrepreneurial' economy (Audretsch and Thurik 2000, 2001). The view that entrepreneurship is an independent production factor like human, physical and knowledge capital has led to the introduction of entrepreneurship capital into the production function (Audretsch and Keilbach 2004). Various studies have shown that entrepreneurship influences economic growth (Parker 2009; Erken et al. 2009). Although there are many indications in the knowledge literature that the (spatial) organization of business has an effect (Audretsch and Feldman 1996; Anselin et al. 1997; Keller 2002) and indications in the entrepreneurship literature that knowledge and its diffusion are important 


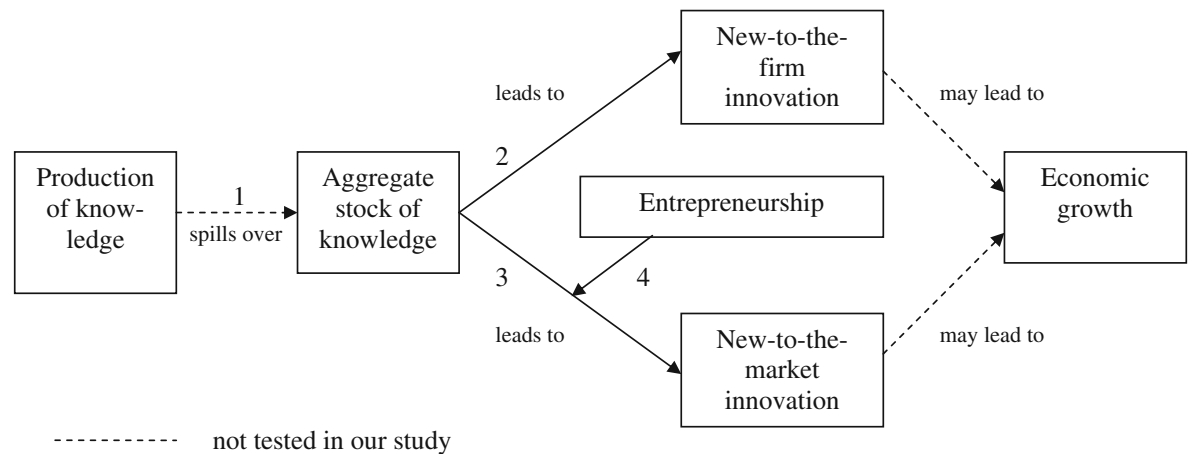

Fig. 1 The moderating role of entrepreneurship in the relationship between knowledge and innovation

(Audretsch and Thurik 2001), only the knowledge spillover theory of entrepreneurship unites these strains of thought (Acs et al. 2009; Braunerhjelm et al. 2010), giving rise to its description as a "missing link" (Acs et al. 2004). Our paper uses the knowledge spillover theory of entrepreneurship to analyze the effect of entrepreneurship on the commercialization of knowledge leading to different innovation outcomes. Knowledge and entrepreneurial activity may ultimately lead to economic growth, but only by first producing innovative products. This link is addressed in the present paper using a panel dataset for the aggregate innovation activity of 21 European countries collected in four time waves. Our results clearly show that entrepreneurship moderates the relationship between knowledge and new-to-the-market innovation but has no impact on the relationship between knowledge and new-to-the-firm innovation. In other words, our results show that countries with a high rate of entrepreneurship perform better in terms of what is sometimes referred to as 'true' innovation (Kleinknecht et al. 2002).

Figure 1 illustrates our conceptual model. The production of knowledge increases the aggregate stock of knowledge (arrow 1). Both existing firms and new firms can draw from this aggregate stock and develop both new-to-thefirm (arrow 2) and new-to-the-market products (arrow 3). ${ }^{10}$ Entrepreneurship moderates the relationship between the aggregate stock of knowledge and the number of new-to-the-market products ('true' innovation performance) (arrow 4), but it has no impact on the relationship between the aggregate

\footnotetext{
${ }^{10}$ Consider the following example: firm A discloses new knowledge (e.g., by filing a patent). Firm B applies this new knowledge to create a product that is similar to the product idea of firm A (which leads to an imitative product). Firm C, however, uses this new knowledge to create a product that is new to both firm A and firm B (which leads to an innovative product).
} 
stock of knowledge and the number of imitative products. ${ }^{11}$ Both new-to-thefirm, imitative products and new-to-the-market products may lead to economic growth. However, the mechanisms involved differ and may depend on the country's level of development (Vandenbussche et al. 2006). We will not expand upon this discussion because it is beyond the scope of our paper.

\subsection{Schumpeterian explanation for the moderating role of entrepreneurship}

Our findings concerning the role of entrepreneurship are consistent with a Schumpeterian view of entrepreneurship and innovation. Schumpeter divided the creative process of economic development into three stages: invention, innovation (commercialization) and imitation. In his early works, Schumpeter argued that entrepreneurs are not necessarily inventors or knowledge creators (Schumpeter 1934); instead, they transform knowledge into products (Brouwer 2002). That is, entrepreneurs are innovators who introduce new products, create new production methods and open new markets. Schumpeter saw the entrepreneur as an agent who can cope with uncertainty, thereby inducing technological change and progress (Brouwer 2002). Therefore, entrepreneurs should be more effective than other agents at successfully commercializing inventions. Braunerhjelm and Svensson (2010) show that the likelihood of the commercial success of an invention increases significantly when the invention is commercialized by an entrepreneur rather than by an inventor. Our findings regarding the role of entrepreneurship clearly support a Schumpeterian view of entrepreneurship and innovation. Entrepreneurship moderates the relationship between a country's level of knowledge and newto-the-market innovation but has no impact on the relationship between knowledge and new-to-the-firm innovation. The former relationship is characterized by a high degree of uncertainty, whereas the latter may not be. The entrepreneur's capacity for risk taking and absorbing uncertainty is more important with new-to-the-market innovation than with new-to-the-firm innovation. The moderating role of entrepreneurship in new-to-the-market innovation is related to the level of product complexity in the manufacturing sector. With increasingly complex products and production processes, imitation is hardly a feasible way for new firms to enter the manufacturing sector (Hobday 1998). A firm's chances of survival increase when it has 'true' innovations. Successful market entry by entrepreneurs requires the ability to turn knowledge into innovation.

\subsection{Implications for innovation and entrepreneurship policy}

Our main finding, that entrepreneurship moderates the relationship between knowledge and 'true' innovation performance, has important policy implica-

\footnotetext{
${ }^{11}$ A different mechanism is suggested by Audretsch et al. (2008), where innovation efforts are assumed to generate technical knowledge and entrepreneurship capital, and the latter two are assumed to lead to economic growth.
} 
tions. From an innovation policy perspective, promoting the production of new knowledge (e.g., by means of R\&D subsidies or university education) is not sufficient; it is equally important for entrepreneurs to turn this new knowledge into innovative products to fuel economic growth. If there are only a few entrepreneurs in a knowledge-intensive region, the so-called Swedish or European paradox (Ejermo and Kander 2006; Audretsch 2007) may emerge, with the implication that commercial opportunities will remain under-exploited or will only be exploited outside the region. In any case, profits will not flow back to the region in which the knowledge was produced. To prevent this situation, policymakers may want to promote entrepreneurship in their own country or region through subsidized loans to high-tech entrepreneurs, regulatory exemptions for innovative new start-ups, or tax benefits. However, we believe that simply encouraging more people to become entrepreneurs is not an effective policy. The government should support those entrepreneurs who take the risk of transforming new knowledge into innovative products and focus less on those entrepreneurs who merely start another shop around the corner. ${ }^{12}$ Many start-ups do not fall into the first category but belong to the latter group (Block et al. 2010a; Koellinger 2008). In fact, prior research shows that many entrepreneurs start their venture out of economic necessity (Block and Sandner 2009; Block and Wagner 2010). An alternative long-term strategy for policymakers would be to promote (entrepreneurship) education to increase the number of qualified and risk-taking entrepreneurs (Block et al. 2011).

\subsection{Limitations and further research}

Our paper has limitations in the scope of the dataset and the measurement of innovation. These limitations suggest opportunities for further research.

Regarding the first limitation, our dataset is limited to the countries participating in the CIS. An extension of the dataset to emerging countries in Asia or Latin America would be interesting. Given prior research about the role of entrepreneurship in emerging economies (Naudé 2011), we would expect the positive effects of entrepreneurship in the commercialization of knowledge into innovations to be even greater. As noted above, the dataset of the GEM (Reynolds et al. 2005) and the recently developed Global and Entrepreneurship Development Index (GEDI, Acs and Szerb 2011) could be used as a source of entrepreneurship data. The difficulty is in finding comparable country-level data about innovation activities that goes beyond information about aggregated levels of R\&D spending.

In terms of measuring innovation, our paper is limited to two specific types of innovation, new-to-the-market and new-to-the-firm innovation. However, the concept of innovation has many different facets and dimensions

\footnotetext{
${ }^{12}$ See also Shane (2009), who discusses at length why simply encouraging more people to become entrepreneurs is a bad public policy.
} 
(Kleinknecht et al. 2002). For example, we would expect entrepreneurship to have a greater effect with regard to radical versus incremental innovation (Arrow 1962). Research by Henderson (1993) suggests that established firms are more likely than entrants to invest in incremental innovation. In addition, incumbent firms seeking to exploit radical innovation are significantly less productive in their research efforts than new firms entering the market.

In addition to the differences between incremental and radical innovation, there may be industry-specific and technology-specific patterns in the role of entrepreneurship with respect to the transformation of knowledge into commercial products. Prior research on the distinction between Schumpeter Mark I and Schumpeter Mark II industries, for example, suggests that the determinants of innovation may be industry- and technology-specific (Breschi et al. 2000; Malerba and Orsenigo 1995).

\section{Concluding remarks}

Additional research is needed to determine how to identify, attract, and support those entrepreneurs who transform knowledge into 'truly' innovative products and thereby increase the competiveness of their particular region. Some questions worth investigating include the following: What types of entrepreneurs turn knowledge into new products (inexperienced versus experienced entrepreneurs)? How should these entrepreneurs be funded (equity versus debt)? What role do VCs and their specific social capital play in the commercialization process? ${ }^{13}$ How does the path to entrepreneurship (e.g., business takeover versus new venture start? ${ }^{14}$ ) influence the entrepreneur's ability to turn knowledge into innovation? What is the role of technology clusters and government-sponsored technology parks with respect to the relationship between entrepreneurship and innovation?

The stagnation of competitiveness in European economies is often attributed to their inability to transform new knowledge into commercially viable products. Policymakers have persistently believed that entrepreneurs play a larger role in this transformation than do large corporations. A wave of policies focusing on the promotion of entrepreneurship has ensued, and the present analysis shows that this policy trend is justified.

Acknowledgements Comments by David Audretsch, Werner Boente, Marcus Dejardin, Hugo Erken, Michael Fritsch, Philipp Koellinger, Eva Lutz, Sandra Phlippen, Christian Roessler, Lorraine Uhlaner, Andre van Stel, and the participants of the DIME workshop in Jena (October 15-17, 2009) and the Entrepreneurship and Innovation Brown Bag Seminar of Erasmus University Rotterdam are gratefully acknowledged. This paper has been written in cooperation with the research program SCALES, carried out by EIM and financed by the Dutch Ministry of Economic Affairs.

\footnotetext{
${ }^{13}$ See Alexy et al. (2012) for a discussion of the social capital of VCs.

${ }^{14}$ See Block et al. (2010b) for a discussion of business takeover versus new venture start.
} 
Open Access This article is distributed under the terms of the Creative Commons Attribution License which permits any use, distribution, and reproduction in any medium, provided the original author(s) and the source are credited.

\section{References}

Acs ZJ (ed) (2010) The knowledge spillover theory of entrepreneurship. Edward Elgar, Cheltenham

Acs ZJ, Armington C (2004) Employment growth and entrepreneurial activity in cities. J Evol Econ 38(8):911-927

Acs ZJ, Szerb L (2011) The global entrepreneurship and development index 2012. Edward Elgar Publishers

Acs ZJ, Varga A (2005) Entrepreneurship, agglomeration and technological change. Small Bus Econ 24(3):323-334

Acs ZJ, Anselin L, Varga A (2002) Patents and innovation counts as measures of regional production of new knowledge. Res Policy 31(7):1069-1085

Acs ZJ, Audretsch DB, Braunerhjelm P, Carlsson B (2004) The missing link: the knowledge filter and entrepreneurship in endogenous growth. CEPR discussion paper no. 4783

Acs ZJ, Braunerhjelm P, Audretsch DB, Carlsson B (2005) The knowledge spillover theory of entrepreneurship. CEPR discussion paper no. 5326

Acs ZJ, Braunerhjelm P, Audretsch DB, Carlsson B (2009) The knowledge spillover theory of entrepreneurship. Small Bus Econ 32(1):15-30

Alexy O, Block J, Sandner P, Ter Wal A (2012) Social capital of venture capitalists and start-up funding. Small Bus Econ. doi:10.1007/s11187-011-9337-4

Anselin L, Varga A, Acs ZJ (1997) Local geographic spillovers between university research and high technology innovations. J Urban Econ 42(3):422-448

Arrow K (1962) Economic welfare and the allocation of resources for invention. In: Welson RR (ed) The rate and direction of economic activity. Princeton University Press, Princeton, pp 609-625

Arundel A (2001) The relative effectiveness of patents and secrecy for appropriation. Res Policy 30(4):611-624

Audretsch DB (1995) Innovation and industry evolution. MIT Press, Cambridge

Audretsch DB (2007) Entrepreneurship capital and economic growth. Oxf Rev Econ Policy 23(1):63-78

Audretsch DB, Feldman MP (1996) R\&D spillovers and the geography of innovation and production. Am Econ Rev 86(3):630-640

Audretsch DB, Keilbach MC (2004) Entrepreneurship capital and economic performance. Region Stud 38(8):949-959

Audretsch DB, Lehmann EE (2005) Does the knowledge spillover theory hold for regions? Res Policy 34(8):1191-1202

Audretsch DB, Thurik AR (2000) Capitalism and democracy in the 21st century: from the managed to the entrepreneurial economy. J Evol Econ 10(1-2):17-34

Audretsch DB, Thurik AR (2001) What is new about the new economy: sources of growth in the managed and entrepreneurial economies. Ind Corp Change 10(1):267-315

Audretsch DB, Boente W, Keilbach MC (2008) Entrepreneurship capital and its impact on knowledge diffusion and economic performance. J Bus Venturing 23(6):687-698

Baumol WJ (2002) The free market innovation machine: analyzing the growth miracle of capitalism. Princeton University Press, Princeton

Benz M, Frey B (2008) Being independent is a great thing: subjective evaluations of selfemployment and hierarchy. Economica 75(298):362-383

Beugelsdijk S (2007) Entrepreneurial culture, regional innovativeness and economic growth. J Evol Econ 17(2):187-210

Block J, Köllinger P (2009) I can't get no satisfaction-necessity entrepreneurship and procedural utility. Kyklos 62(1):191-209 
Block J, Sandner P (2009) Necessity and opportunity entrepreneurs and their duration in selfemployment: evidence from German micro data. J Ind Compet Trade 9(2):117-137

Block J, Wagner M (2010) Necessity and opportunity entrepreneurs in Germany: characteristics and earnings differentials. Schmalenbach Business Review 62(2):154-174

Block J, Sandner P, Spiegel F (2010a) How do risk attitudes differ within the group of entrepreneurs? The role of motivation and procedural utility. SSRN working paper

Block JH, Thurik, AR, Van der Zwan, PW, Walter S (2010b) Business takeover or new venture? Individual and environmental determinants from a cross-country study. ERIM research paper ERS-2010-042-ORG. http://hdl.handle.net/1765/21239

Block J, Hoogerheide L, Thurik R (2011) Education and entrepreneurial choice: an instrumental variables analysis. Int Small Bus J. doi:10.1177/0266242611400470

Braunerhjelm P (2008) Entrepreneurship, knowledge and economic growth. Foundations and Trends in Entrepreneurship 4(5):451-533

Bolton MK (1993) Imitation versus innovation: lessons to be learned from the Japanese. Organ Dyn 21(3):30-45

Bottazzi L, Peri G (2003) Innovation and spillovers in regions: evidence from European patent data. Eur Econ Rev 47(4):687-710

Braunerhjelm P, Svensson P (2010) The inventor's role: was Schumpeter right? J Evol Econ 20(3):413-444

Braunerhjelm P, Acs ZJ, Audretsch DB, Carlsson B (2010) The missing link: knowledge diffusion and entrepreneurship in endogenous growth. Small Bus Econ 34(2):104-125

Breschi S, Lissoni F (2001) Knowledge spillovers and local innovation systems: a critical survey. Ind Corp Change 10(4):975-1005

Breschi S, Malerba F, Orsenigo L (2000) Technological regimes and Schumpeterian patterns of innovation. Econ J 110(463):388-410

Breusch TS, Pagan AR (1980) The Lagrange multiplier test and its application to model specification in econometrics. Rev Econ Stud 47(1):239-253

Brockhaus RH (1980) Risk taking propensity of entrepreneurs. Acad Manage J 23(3):509-520

Brouwer MT (2002) Weber, Schumpeter and Knight on entrepreneurship and economic development. J Evol Econ 12(1):83-105

Cantner U, Gaffard J, Nesta L (2008) Schumpeterian perspectives on innovation, competition and growth. J Evol Econ 18(3):291-293

Carlsson B, Fridh A (2002) Technology transfer in United States universities. J Evol Econ 12(1):199-232

Carlsson B, Acs ZJ, Audretsch DB, Braunerhhjem P (2009) Knowledge creation, entrepreneurship and economic growth: a historical review. Ind Corp Change 18(6):1193-1229

Carree MA, Thurik AR (2010) The impact of entrepreneurship on economic growth. In: Acs ZJ, Audretsch DB (eds) Handbook of entrepreneurship research, international handbook series on entrepreneuship, vol 5. Springer, New York, pp 557-594

Carree MA, van Stel A, Thurik AR, Wennekers S (2002) Economic development and business ownership: an analysis using data of 23 OECD countries in the period 1976-1996. Small Bus Econ 19(3):271-290

Cohen WM, Levinthal DA (1989) Innovation and learning: the two faces of R\&D. Econ J 99(397):569-596

Ejermo O, Kander A (2006) The Swedish paradox. CIRCLE Electronic Working Paper Series 2006/01, CIRCLE, Lund

Erken H, Donselaar P, Thurik AR (2009) Total factor productivity and the role of entrepreneurship. Tinbergen Institute discussion papers TI09-034/3, Rotterdam, Netherlands

Furman JL, Porter ME, Stern S (2002) The determinants of national innovative capacity. Res Policy 31(6):899-933

Glaeser EL, Kallal HD, Scheinkman JA, Shleifer A (1992) Growth in cities. J Polit Econ 100(6):1126-1152

Griliches Z (1998) R\&D and productivity: the econometric evidence. University of Chicago Press, Chicago

Griliches Z (2000) R\&D, education, and productivity. A retrospective. Harvard University Press, Cambridge

Hauser J, Zettelmeyer F (1997) Metrics to evaluate R, D \& E. Res Technol Manag 40(4):32-38 
Hausman JA (1978) Specification tests in econometrics. Econometrica 46(6):1251-1271

Henderson R (1993) Underinvestment and incompetence as responses to radical innovation: evidence from the photolithographic alignment equipment industry. Rand J Econ 24(2): 248-271

Hobday M (1998) Product complexity, innovation and industrial organization. Res Policy 26(6):689-710

Hoelzl W (2009) Is the R\&D behaviour of fast-growing SMEs different? Evidence from CIS III data for 16 countries. Small Bus Econ 33(1):59-75

Jaffe AB, Trajtenberg M, Henderson R (1993) Geographic localization of knowledge spillovers as evidenced by patent citations. Q J Econ 108(3):577-598

Jaffe AB, Trajtenberg M, Fogarty MS (2000) Knowledge spillovers and patent citations: evidence from a survey of inventors. Am Econ Rev 90(2):215-218

Jovanovic B (1982) Selection and the evolution of industry. Econometrica 50(3):649-670

Keller W (2002) Geographic localization of international technology diffusion. Am Econ Rev 92(1):120-142

Kihlstrom RE, Laffont JJ (1979) A general equilibrium entrepreneurial theory of firm formation based on risk aversion. J Polit Econ 1(4):719-748

Kleinknecht A, Van Montfort K, Brouwer E (2002) The non-rival choice between innovation indicators. Econ Innov New Technol 11(2):109-121

Koellinger P (2008) Why are some entrepreneurs more innovative than others? Small Bus Econ 31(1):21-37

Kortum SS, Lerner J (2000) Assessing the contribution of venture capital to innovation. RAND J Econ 31(4):674-692

Lucas RE (1988) On the mechanics of economic development. J Monet Econ 22(1):3-42

Lucas RE (1993) Making a miracle. Econometrica 61(2):251-272

Mairesse J, Mohnen P (2002) Accounting for innovation and measuring innovativeness: an illustrative framework and an application. Am Econ Rev 92(2):226-231

Mairesse J, Mohnen P (2005) The importance of R\&D for innovation: a reassessment using French survey data. J Technol Transf 30(1-2):193-197

Malerba F (2006) Innovation and the evolution of industries. J Evol Econ 16(1-2):3-23

Malerba F, Orsenigo F (1995) Schumpeterian patterns of innovation. Camb J Econ 19(1): $47-65$

Mansfield E (1965) Rates of return from industrial research and development. Am Econ Rev 55(1/2):310-322

McClelland DC (1961) The achieving society. Van Nostrandt, Princeton

Naudé W (2011) Entrepreneurship and economic development. Palgrave McMillan, Houndmills, Basingstoke

Ortega-Argilés R, Vivarelli M, Voigt P (2009) R\&D in SMEs: a paradox? Small Bus Econ 33(1): 3-11

Park G, Park Y (2006) On the measurement of patent stock as knowledge indicators. Technol Forecast Soc Change 73(7):793-812

Parker S (2009) The economics of entrepreneurship. Cambridge University Press, Cambridge

Reynolds PD, Bosma N, Autio E, Hunt S, De Bono N, Servais I, Lopez-Garcia P, Chin N (2005) Global entrepreneurship monitor: data collection design and implementation 19982003. Small Bus Econ 24(3):205-231

Romer PM (1986) Increasing returns and long-run growth. J Polit Econ 94(5):1002-1037

Romer PM (1990) Endogenous technical change. J Polit Econ 98(5):S71-S102

Schere JC (1982) Tolerance of ambiguity as a discriminating variable between entrepreneurs and managers. In: Academy of management proceedings, pp 404-408

Scherer FM, Harhoff D, Kukies J (2000) Uncertainty and the size distribution of rewards from innovation. J Evol Econ 10(1-2):175-200

Schewe G (1996) Imitation as a strategic option for external acquisition of technology. J Eng Technol Manag 13(1):55-82

Schumpeter JA (1934) The theory of economic development. Harvard University Press, Cambridge

Shane S (2009) Why encouraging more people to become entrepreneurs is a bad public policy. Small Bus Econ 33(2):141-149 
Shane S, Venkataraman S (2000) The promise of entrepreneurship as a field of research. Acad Manag Rev 25(1):217-226

Timmons JA (1976) Characteristics and role demands of entrepreneurship. Am J Small Bus 3(1):5-17

Van Praag CM, Versloot PH (2007) What is the value of entrepreneurship? A review of recent research. Small Bus Econ 29(4):351-382

Van Stel A (2005) COMPENDIA: harmonizing business ownership data across countries and over time. Int Entrep Manag J 1(1):105-123

Vandenbussche J, Aghion P, Meghir C (2006) Growth, distance to frontier and composition of human capital. J Econ Growth 11(2):97-127

Varga A (2000) Local academic knowledge spillovers and the concentration of economic activity. J Reg Sci 40(2):289-309

Werker C, Athreye S (2004) Marshall's disciples: knowledge and innovation driving regional economic development and growth. J Evol Econ 14(5):505-523

Wiggins S (1995) Entrepreneurial enterprises, endogenous ownership, and the limits to firm size. Econ Inq 33(1):54-69

Wooldridge JM (2002) Econometric analysis of cross section and panel data. The MIT Press, Cambridge 